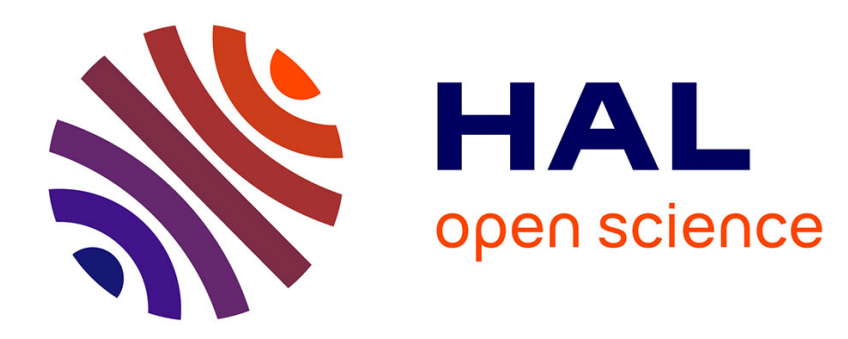

\title{
TiO2 (B)/activated carbon non-aqueous hybrid system for energy storage
}

Thierry Brousse, René Marchand, Pierre-Louis Taberna, Patrice Simon

\section{To cite this version:}

Thierry Brousse, René Marchand, Pierre-Louis Taberna, Patrice Simon. TiO2 (B)/activated carbon non-aqueous hybrid system for energy storage. Journal of Power Sources, 2006, 158 (1), pp.571-577. 10.1016/j.jpowsour.2005.09.020 . hal-03482058

\section{HAL Id: hal-03482058 https://hal.science/hal-03482058}

Submitted on 15 Dec 2021

HAL is a multi-disciplinary open access archive for the deposit and dissemination of scientific research documents, whether they are published or not. The documents may come from teaching and research institutions in France or abroad, or from public or private research centers.
L'archive ouverte pluridisciplinaire HAL, est destinée au dépôt et à la diffusion de documents scientifiques de niveau recherche, publiés ou non, émanant des établissements d'enseignement et de recherche français ou étrangers, des laboratoires publics ou privés. 


\title{
$\underline{\mathrm{TiO}}_{\underline{2}}$ (B)/activated carbon non-aqueous hybrid system for energy storage
}

Thierry Brousse, René Marchand, Pierre-Louis Taberna and Patrice Simon

Laboratoire de Génie des Matériaux, Ecole Polytechnique de l’Université de Nantes, La Chantrerie, rue Christian Pauc, BP50609, 44306 Nantes Cedex 3, France

Centre Inter-universitaire de Recherche et d'Ingénierie des MATériaux (CIRIMAT, UMR 5085), Université Paul Sabatier, Bat 2 R1, 118 route de Narbonne, 31062 Toulouse Cedex 4, France

\begin{abstract}
$\underline{\text { Abstract }}$
$\mathrm{TiO}_{2}(\mathrm{~B})$ has been investigated as a possible candidate to replace $\mathrm{Li}_{4} \mathrm{Ti}_{5} \mathrm{O}_{12}$ as a negative electrode for Li-ion battery. The starting compound was synthesized by a simple solid state reaction followed by hydrolysis. Long term stability of the $\mathrm{TiO}_{2}(\mathrm{~B})$ electrode can be obtained by limiting lithium intercalation between 0.25 and $0.35 \mathrm{Li}^{+}$per unit formula. High cycling rates (up to $24 C$ ) have been used without noticeable degradation of the electrode. A non-aqueous hybrid energy storage device using $\mathrm{TiO}_{2}(\mathrm{~B})$ as the negative electrode and activated carbon as the positive was assembled. The maximum hybrid cell voltage can be set between $2.75 \mathrm{~V}$ and $3.5 \mathrm{~V}$. The cells exhibit energy densities between $45 \mathrm{~W} \mathrm{~kg}^{-1}$ and $80 \mathrm{~W} \mathrm{~kg}^{-1}$ with power densities in the range $240-420 \mathrm{~W} \mathrm{~kg}^{-1}$ which is compatible with a fast charging/discharging storage device, intermediate between electrochemical double layer capacitor and $\mathrm{Li}$-ion batteries.
\end{abstract}

Keywords: Lithium battery; Supercapacitor; Electrochemical capacitor; Hybrid; $\mathrm{TiO}_{2}$; Activated carbon

1. Introduction

2. Experimental

2.1. $\mathrm{TiO} 2(\mathrm{~B})$

2.2. Activated carbon

2.3. Electrodes preparation

2.4. Electrochemical tests

3. Results and discussion

3.1 .

3.2. Materials characterizations

4. Conclusion

Acknowledgements

References

\section{Introduction}

Charge storage devices covered a wide range of applications which required either high energy density (batteries) or high power density (capacitors) [1]. Electrochemical capacitors [2], so called supercapacitors, have bridged the gap between these two extreme kinds of devices. In the recent years, new devices have been designed to work at the border of standard capacitors and 
supercapacitors on one side [3] and [4] and of supercapacitors and batteries on the other side [5], [6], [7], [8] and [9] of a Ragone plot. This last type of devices are of great interest for systems requiring fast charge/discharge rate while keeping a reasonable energy density. Such systems can find applications both in consumer electronics (fast charge of portable phones, for example) and in traction devices. The clever concept of mixed battery/supercapacitor cell was introduced by Amatucci et al. [5], [6], [7] and [8] in a serie of papers relating both fundamentals and applied electrochemistry in relation with the choice of materials and the design of electrodes. Basically, the cell consists of $\mathrm{Li}^{+}$intercalation negative electrode coupled with an electrochemical double layer capacitance (EDLC) positive electrode immersed in a non-aqueous media, usually a lithium salt $\left(\mathrm{LiPF}_{6}\right)$ dissolved in an organic solvent (acetonitrile, propylene carbonate, etc. ...). In order to stand severe cycling performance required for such an hybrid device, i.e. long term cycling ability, fast charging and/or discharging rates, high energy density, the intercalation compound used as the negative electrode has to suffer few volume expansion upon lithium intercalation while maintaining a reasonable amount of intercalated ions during every cycle. $\mathrm{Li}_{4} \mathrm{Ti}_{5} \mathrm{O}_{12}[10]$, [11], [12], [13], [14], [15], [16] and [17] fulfils these requirements, and impressive performance have been reported when it was used in a hybrid cell together with a positive activated carbon electrode [5], [6] and [7]. Specific capacity as high as $160 \mathrm{mAh} \mathrm{g}^{-1}$ has been measured on nanocrystalline material with only $2 \%$ loss within 800 cycles [5]. Other lithiated Ti-based compounds such as ramsdellite titanate have shown nice electrochemical properties versus lithium [18]. Another kind of titanate, $\mathrm{TiO}_{2}$ (B) [19] and [20], is also able to accommodate reasonable lithium intercalation without sensible distortion in the structure. The electrochemistry of $\mathrm{Li}^{+}$intercalation in $\mathrm{TiO}_{2}$ (B) has been detailed in a serie of papers [20], [21], [22], [23], [24], [25], [26] and [27] pointing out the superiority of this material over other titanate such as anatase [23]. Zukalovă et al. [27] recently summarized these studies, and highlighted the pseudocapacitive nature of lithium storage in $\mathrm{TiO}_{2}(\mathrm{~B})$.

In this study, we decided to investigate the use of $\mathrm{TiO}_{2}(\mathrm{~B})$ as negative electrode in a hybrid device together with an activated carbon positive electrode, with special care to the long term cycling ability, the specific capacity and the fast cycling rate behavior of the $\mathrm{TiO}_{2}(\mathrm{~B})$ electrode.

\section{Experimental}

\section{1. $\mathrm{TiO}_{2}(\mathrm{~B})$}

The synthesis of our pristine titanate was performed according to the method developed by one of the authors (Marchand et al. [19]) in 1982. Briefly, the starting material $\mathrm{K}_{2} \mathrm{Ti}_{4} \mathrm{O}_{9}$ is obtained by heating $\mathrm{KNO}_{3}$ (Merck, purity) and $\mathrm{TiO}_{2}$ (anatase, Prolabo purity) in the molar ratio 1:2 at $1000{ }^{\circ} \mathrm{C}$ for $6 \mathrm{~h}$. The resulting solid is ground in agate mortar and then hydrolysed for 3 days in $\mathrm{HNO}_{3}<0.5 \mathrm{M}\left(10^{-3} \mathrm{~mol} \mathrm{~K}_{2} \mathrm{Ti}_{4} \mathrm{O}_{9}\right.$ in $\left.100 \mathrm{~cm}^{3} \mathrm{HNO}_{3}\right)$. After filtering, the powder was heated at $500{ }^{\circ} \mathrm{C}$ in air for $15 \mathrm{~h}$.

\subsection{Activated carbon}

Activated carbon was PICACTIF obtained from PICA company. The resistivity was $1.99 \Omega \mathrm{cm}$ [28].

Different techniques were used to characterize the electrode materials. XRD patterns were 
recorded with a Siemens D-5000 diffractometer, using the $\mathrm{Cu} \mathrm{K \alpha}$ radiation. The particle size and morphology of the films were studied with a scanning electron microscope (SEM, LEO stereoscan 440) coupled with an energy dispersive X-ray analyzer (EDS, Link Isis, Oxford Instrument). Multiple point Brunauer-Emmett-Teller (BET) surface area measurements were made with a Micromeritic Flowsorb II/2300 surface area analyzer or an ASAP 2000 Micromeritic equipment using $\mathrm{N}_{2}$ gas.

\subsection{Electrodes preparation}

The $\mathrm{TiO}_{2}$ (B) powder was mixed with acetylene black and Poly(vinylydene fluoride), PVDF, dissolved in $n$-methyl pyrolidinone, NMP, $6 \mathrm{wt} \%$, in a weight ratio 71.5:22.5:6.0. The slurry was mixed overnight to obtain a homogeneous black paste which is then barcoated on a copper foil and the solvent is removed at $100^{\circ} \mathrm{C}$ in air for $2 \mathrm{~h}$. Pieces $14 \mathrm{~mm}$ diameter were then cut and used as the electrode in homemade cells assembled inside an argon filled glove box. The average amount of $\mathrm{TiO}_{2}$ (B) in a round piece of electrode is about $2.5 \mathrm{mg}$. Each electrode was carefully weighted before use and several electrodes were tested to assume the reproducibility of the electrochemical behavior.

Activated carbon electrodes were prepared by laminating dried active material onto $4 \mathrm{~cm}^{2}$ aluminium current collector. Current collector is a treated-Al grid collector (100 $\mu \mathrm{m}$ thick) covered by a conductive paint. Composition of the active material is $95 \%$ of activated carbon PICACTIF and $5 \%$ of Polytetrafluoroethylene as binder (PTFE).

\subsection{Electrochemical tests}

Samples were tested with a Mac-Pile equipment (BioLogic), using a two-electrodes cell and metallic lithium as the counter electrode. The electrolyte used was $1 \mathrm{M}$ solution of $\mathrm{LiPF}_{6}$ in ethylene carbonate:diethyl carbonate (Merck), with a molar ratio of 1:2. Glass fiber paper was used as separator. Alternatively, an Arbin BT2000 battery tester was used to perform the threeelectrode measurements, with $\mathrm{TiO}_{2}$ (B) as the negative (working electrode), PICACTIF as the positive (counter electrode) and lithium as the reference electrode.

\section{$\underline{\text { 3. Results and discussion }}$}

\subsection{Materials characterizations}

Purity of the $\mathrm{K}_{2} \mathrm{Ti}_{4} \mathrm{O}_{9}$ starting compound was checked by X-ray diffraction and found in excellent agreement with JCPDF-file 32-0861. After hydrolysis and thermal treatment X-ray diffraction pattern of the $\mathrm{TiO}_{2}$ (B) powder is shown in Fig. 1 and corresponds to JC-PDS file 35-0088. The space group is monoclinic $\mathrm{C} 2 / \mathrm{m}$ with following cell parameters: $a=1.2163(5) \mathrm{nm}$, $b=0.3735(2) \mathrm{nm}, c=0.6451(2) \mathrm{nm}, \beta=107.29(5)^{\circ}$. The structure consists of $\mathrm{TiO}_{6}$ octahedra arranged in the perovskite $\mathrm{ReO}_{3}$ subunits assembled in the same plane $(a, c)$ by edge-sharing. The idealized tridimensionnal framework is built up of such edge sharing subunits. A more detailed description of the structure can be found elsewhere [19], [20] and [27]. The important feature is the presence of parallel infinite channels along the $\left[\begin{array}{lll}0 & 1 & 0\end{array}\right]$ axis. These tunnels provide intercalation sites in which $\mathrm{Li}^{+}$ions can be accommodated without any significant distortion of the structure [23]. 
Fig. 1. X-ray diffraction pattern of $\mathrm{TiO}_{2}(\mathrm{~B})$ powder $(\mathrm{Cu} \mathrm{K} \alpha)$.

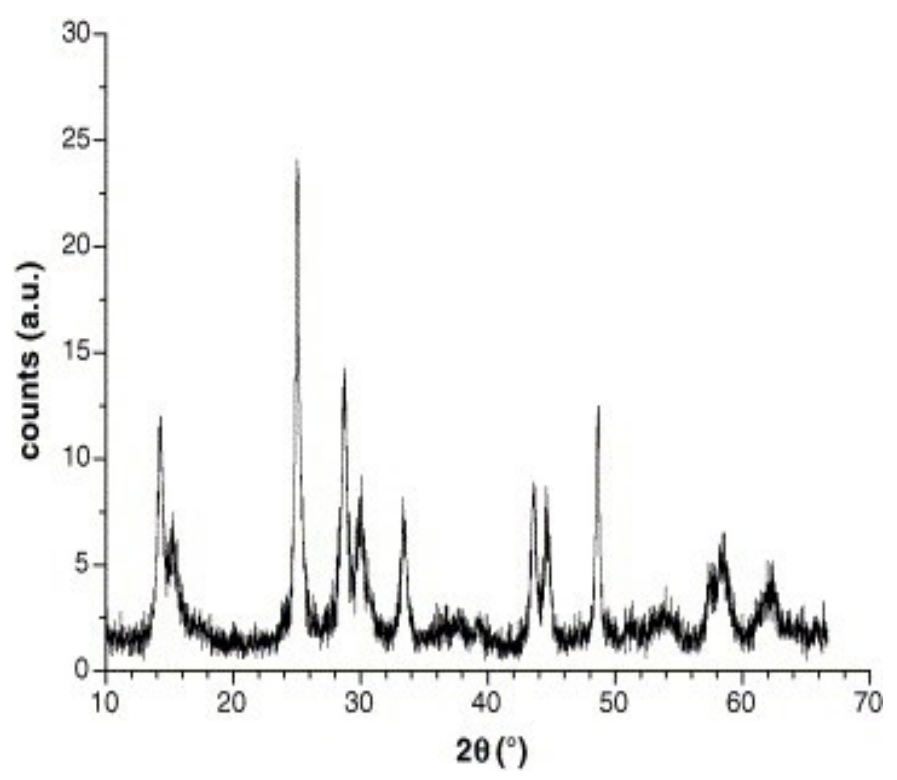

A SEM picture of the $\mathrm{TiO}_{2}$ (B) powder is shown in Fig. 2a and 2b. The powder consists of small needle shaped grains, several micrometers long, with a prismatic section of about $0.3 \mu \mathrm{m} \times 0.1 \mu \mathrm{m}$. A detail of such prismatic grains can be seen on Fig. $2 \mathrm{~b}$. EDX analysis reveals less than 1 at $\% \mathrm{~K}$ per $\mathrm{TiO}_{2}$ unit formula.

Fig. 2. SEM micrographs of the starting $\mathrm{TiO}_{2}$ (B) powder: (a) general view of the grains size and shape and (b) detail of a particle evidencing the "bi-dimensionnal" microstructure (white bar on the left hand corner is $1 \mu \mathrm{m}$ ).
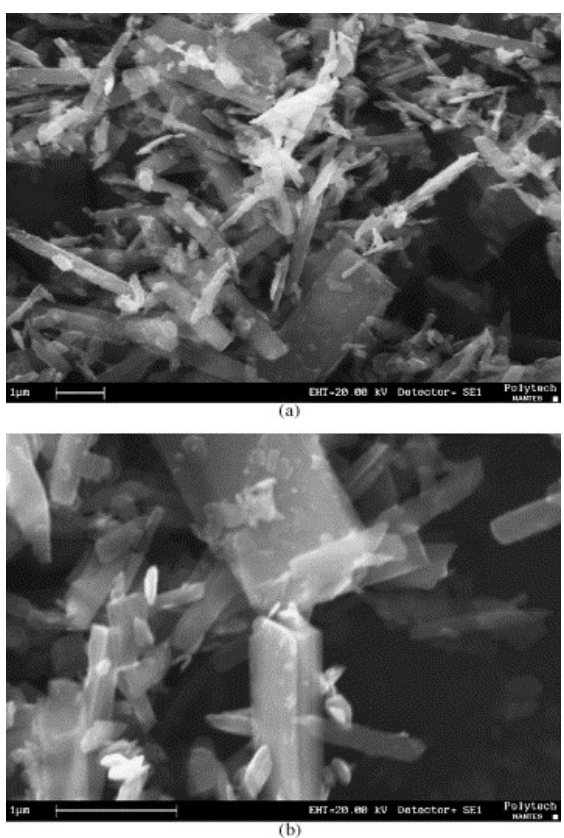
The measured BET surface area of $8 \pm 1 \mathrm{~m}^{2} \mathrm{~g}^{-1}$ is in good agreement with an estimated value calculated with the microscopic geometrical parameters indicated above $\left(7 \mathrm{~m}^{2} \mathrm{~g}^{-1}\right)$, thus indicating that the starting $\mathrm{TiO}_{2}$ (B) powder mainly consists of "bulk" grains without any porosity. This assumption is of importance when discussing the electrochemical behavior of this material since the low surface area value precludes that "surface" phenomena such as capacitive or pseudocapacitive behavior will not be the main parameters for controlling the capacity value of the material. It also suggests that future efforts can be made to improve the surface area of the $\mathrm{TiO}_{2}$ (B) powder, in order to enhance its electrochemical properties.

Table 1 lists the porous characteristics of the PICACTIF BP10 activated carbon which is depicted in Fig. 3. The $10 \mu \mathrm{m}$ wide grains show impressive surface area $\left(2300 \mathrm{~m}^{2} \mathrm{~g}^{-1}\right)$, thus indicating that the activation treatment led to a highly porous material with a high mesoporous volume, suitable for good ion adsorption and then high specific capacitance $\left(\mathrm{F}^{-1}\right)$.

Table 1.

Porous volume and BET surface area of the PICACTIF BP10 activated carbon used

\begin{tabular}{lc}
\hline BET Surface $\left(\mathrm{m}^{2} \mathrm{~g}^{-1}\right)$ & 2300 \\
Median diameter $(\AA)$ & 23.4 \\
Microporous volume $<20 \AA\left(\mathrm{cm}^{3} \mathrm{~g}^{-1}\right)$ & 0.60 \\
$\begin{array}{l}\text { Mesoporous volume } \\
20<\text { size }<500 \AA\left(\mathrm{cm}^{3} \mathrm{~g}^{-1}\right)\end{array}$ & 0.72 \\
Total volume $<500 \AA\left(\mathrm{cm}^{3} \mathrm{~g}^{-1}\right)$ & 1.32 \\
\hline
\end{tabular}

Fig. 3. SEM micrograph of the PICACTIF activated carbon powder (white bar is $10 \mu \mathrm{m})$.

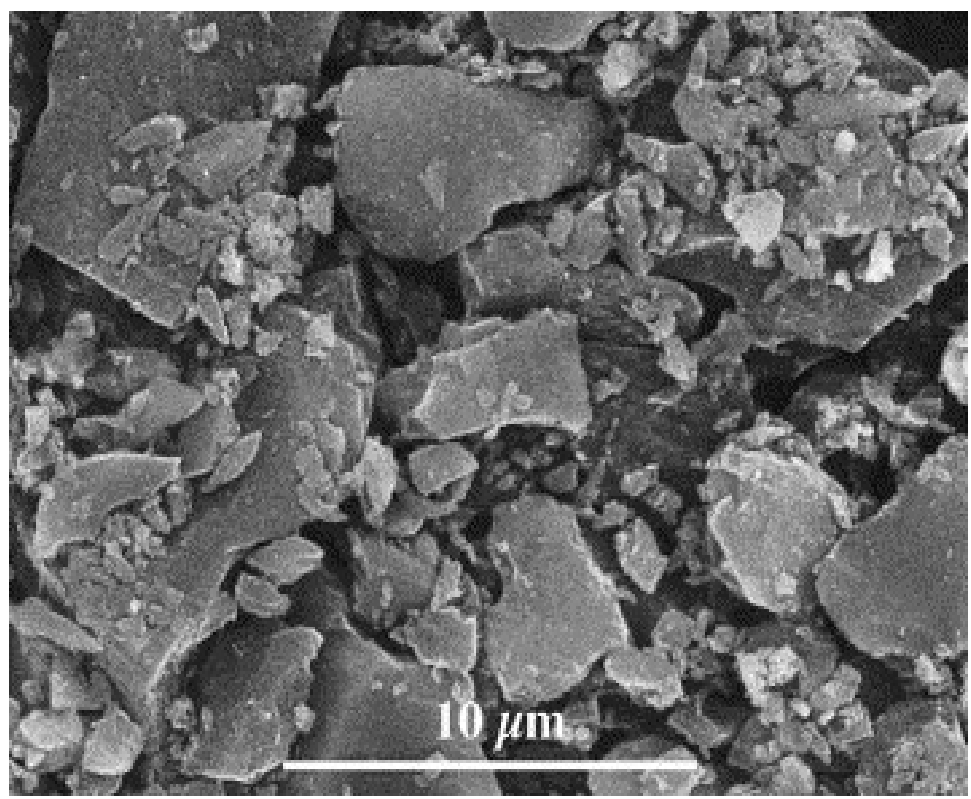




\subsection{Electrochemical behavior}

The electrochemical behavior of $\mathrm{TiO}_{2}$ (B) has already been investigated in detail in many papers [20], [21], [22], [23], [24], [25], [26] and [27]. The most pertinent conclusion is the possibility of the electrochemical intercalation of lithium up to 0.75 ions per unit formula in "standard" powder and up to $0.82 \mathrm{Li}$ in hydrothermally grown $\mathrm{TiO}_{2}(\mathrm{~B})$ nanowires [26]. The first value $(0.75 \mathrm{Li})$ was achieved with the powder used in this study at $C / 10$ rate. A typical cyclic voltammogram of $\mathrm{TiO}_{2}$ (B) electrode is shown on Fig. 4. One cathodic and one anodic waves can be distinguished at, respectively, $1.4 \mathrm{~V}$ and $1.8 \mathrm{~V}$ versus $\mathrm{Li}^{+} / \mathrm{Li}$. Integration of the voltammetric charge between $0.8 \mathrm{~V}$ and $2.3 \mathrm{~V}$ versus $\mathrm{Li}^{+} / \mathrm{Li}$ gives a first cycle capacity of $0.5 \mathrm{Li}$ which is obtained at approximately C/4 rate.

Fig. 4. $\mathrm{CV}$ of the $\mathrm{TiO}_{2}$ (B) electrode at $0.1 \mathrm{mV} \mathrm{s}^{-1}$ (see Section $\underline{2}$ for preparation details).

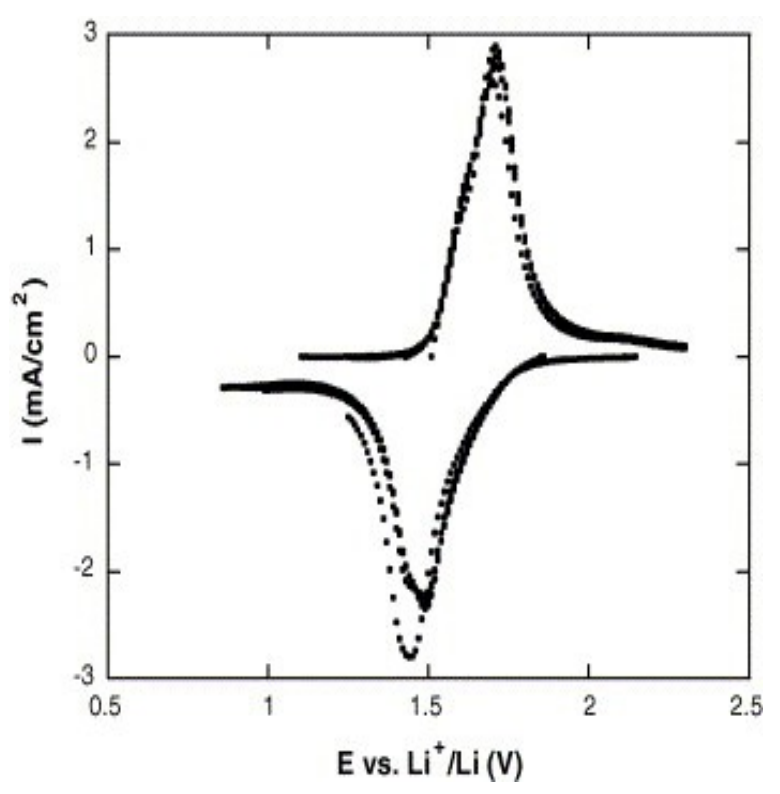

Upon oxidation, only 0.37 lithium are de-intercalated from the electrode, thus confirming that the $\mathrm{Li}^{+}$insertion reversibility is rather poor in $\mathrm{TiO}_{2}$ (B) as stated in previous works [21]. However, this value stabilizes at $0.36 \mathrm{Li}^{+}$after a few cycles. This value corresponds to $120 \mathrm{mAh} \mathrm{g}^{-1}$ which is somewhat lower than the $135 \mathrm{mAh} \mathrm{g}^{-1}$ found for $\mathrm{Li}_{4} \mathrm{Ti}_{5} \mathrm{O}_{12}$ [5]. Since an irreversible capacity is unlikable in the future hybrid device, we decided to limit the lithium intercalation during each cycle. Values between 0.25 and 0.35 lithium per $\mathrm{TiO}_{2}$ (B), i.e. $84-117 \mathrm{mAh} \mathrm{g}^{-1}$, were tested as the intercalation limit. These values are not too penalizing for the system since the limiting electrode in terms of capacity will be the activated carbon on the positive side. While limiting lithium insertion to $0.25 \mathrm{Li}^{+}$per $\mathrm{TiO}_{2}$ (B), we observed a drift of the electrode potential toward lower values as the number of discharges is increased, thus reaching a steady state after a few cycles (ig. 5 ) at $6 \mathrm{C}$ rate, i.e. discharging (and charging) the electrode in $10 \mathrm{~min}$. This potential drift can be seen in Fig. 
$\underline{5}$, starting from $1.45 \mathrm{~V}$ on the first discharge and decreasing to $1.35 \mathrm{~V}$ on the sixth cycle.

Obviously, during the first few cycles, an irreversible capacity is observed between the discharge and the charge of the electrode. The irreversible capacity reaches 0.09 lithium on the first cycle and this value gradually decreases to zero after six cycles. These first cycles corresponds to some kind of activation process, which means that the electrode does not reach immediately its steady state but needs to be cycled according to the procedure mentioned above.

Fig. 5. Galvanostatic charge/discharge of a $\mathrm{TiO}_{2}$ (B) electrode at $6 \mathrm{C}$ rate, limiting the intercalated lithium amount to $0.25 \mathrm{Li}^{+} / \mathrm{TiO}_{2}$ per cycle (see Section $\underline{2}$ for preparation details).

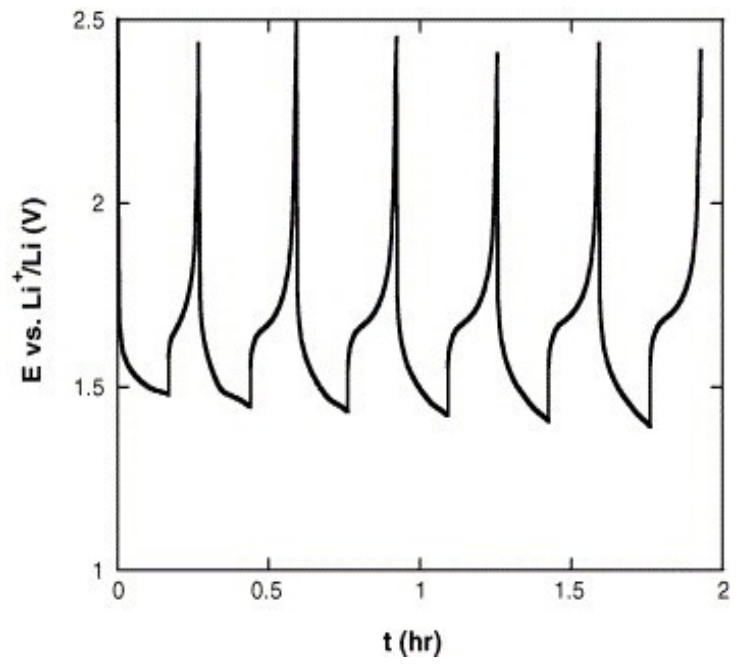

Similar tests performed at the same rate, with a limitation of $0.35 \mathrm{Li}^{+}$per $\mathrm{TiO}_{2}\left(117 \mathrm{mAh} \mathrm{g}^{-1}\right)$ lead to the same behavior, although at very fast charging rates it becomes difficult to maintain such a high capacity.

The capacitive component of the $\mathrm{TiO}_{2}$ (B) electrode can be estimated from the BET surface area $\left(8 \mathrm{~m}^{2} \mathrm{~g}^{-1}\right)$ and the value reported by Conway [2] for EDLC capacitor based on oxides (20$30 \mu \mathrm{F} \mathrm{cm}^{-2}$ ). Taking into account the highest surface capacitance value leads to $3 \mathrm{~F} \mathrm{~g}^{-1}$, i.e. less than $1 \mathrm{mAh} \mathrm{g}^{-1}$ which is far below the specific capacity values measured during the galvanostatic tests. Subsequently, it can be assumed that the capacitive behavior of the $\mathrm{TiO}_{2}(\mathrm{~B})$ electrode is negligible compared to the faradic intercalation processes.

Fig. 6 exhibits the dependance of the capacity versus the charge/discharge rate of the $\mathrm{TiO}_{2}(\mathrm{~B})$ electrode with the same limitation for lithium intercalation $\left(0.25-0.35 \mathrm{Li}^{+}\right.$per $\left.\mathrm{TiO}_{2}\right)$. Even at very fast cycling rate $(24 C$, i.e. charge + discharge in $5 \mathrm{~min})$, the capacity still compatible with a high energy density device. Additionnally, high cycling rates $(>15 C)$ do not seem to affect the electrode behavior which recovered its pristine performance when lower rates are used (3-10C). One can notice the excellent reproducibility of the electrochemical performance recorded on several different electrodes fabricated with different batches of $\mathrm{TiO}_{2}(\mathrm{~B})$. Note that extreme 
conditions have been used to gather the data of Fig. 6 since both the charge and the discharge were performed at the same fast rate.

Fig. 6. Dependance of the capacity versus the charge/discharge rate. Each symbol represents a $\mathrm{TiO}_{2}$ (B) electrode tested at different cycling rates. The same rate was used for the charge and the discharge. Lithium intercalation was limited between 0.25 and $0.35 \mathrm{Li}^{+} / \mathrm{TiO}_{2}$ per cycle.

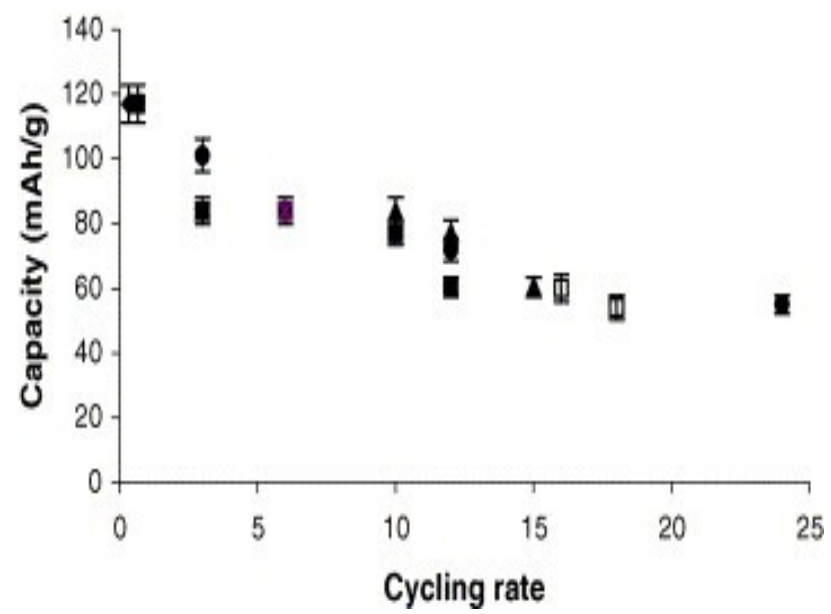

The cycling behavior of $\mathrm{TiO}_{2}(\mathrm{~B})$ electrodes has also been investigated. Fig. 7 compares the cycling behavior of $\mathrm{TiO}_{2}$ anatase $\left(\mathrm{BET}=65 \mathrm{~m}^{2} \mathrm{~g}^{-1}\right)$ and two electrodes of $\mathrm{TiO}_{2}(\mathrm{~B})$. For both $\mathrm{TiO}_{2}$ (B) electrodes, an "activation" process takes place during the first cycles as previously explained, leading to a poor reversible capacity on the first cycle, followed by a sharp increase in the specific capacity which reaches a steady state after six cycles. Such an activation procedure is not easy to achieve in a practical electrochemical system, however a careful control of the weight ratio of active materials both in the negative and positive sides as well as the use of "clever" charging devices can enable to achieve this process.

Fig. 7. Cycling behavior of $\mathrm{TiO}_{2}$ anatase (black dots) and $\mathrm{TiO}_{2}(\mathrm{~B})$ electrodes (open squares and open circles) tested at different cycling rates (see text for experimental details and cycling information). Charge rate are indicated above or below the symbols. 

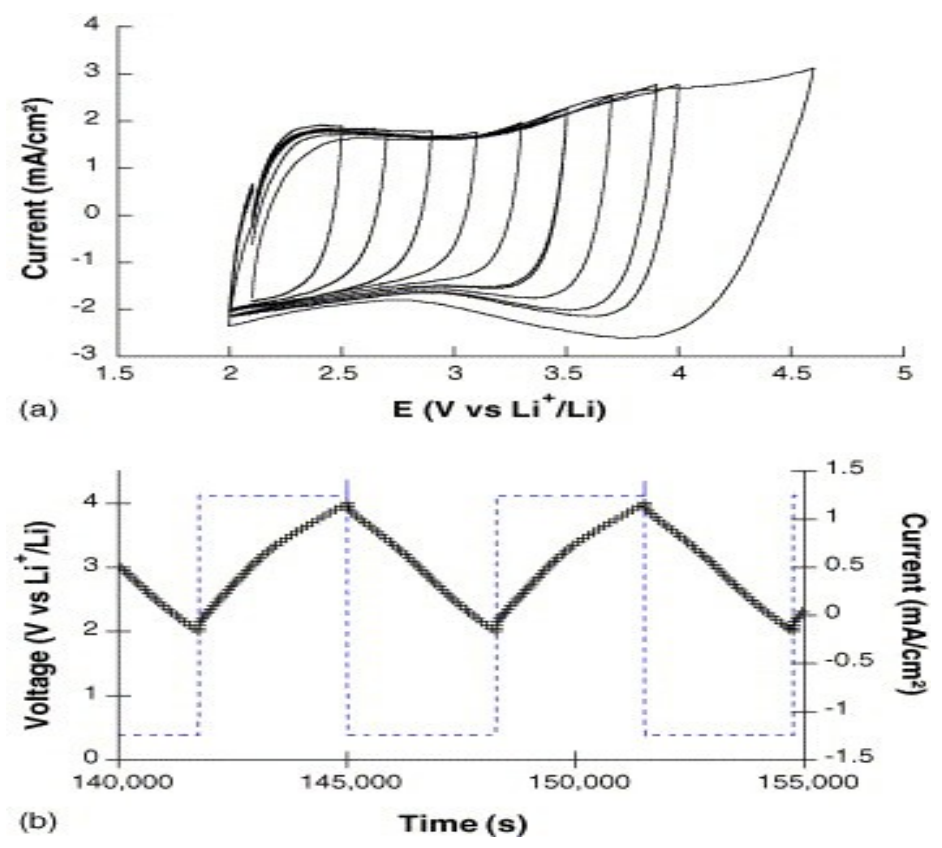

At $6 C$ cycling rate (applied both during charge and discharge), a steady capacity of $84 \mathrm{mAh} \mathrm{g}^{-1}$ is measured over 450 cycles when the lithium insertion is limited to $0.25 \mathrm{Li}^{+}$per cycle for the $\mathrm{TiO}_{2}$ (B) electrode (open circles in Fig. 7). When lithium insertion is limited at $0.35 \mathrm{Li}^{+}$per cycle, the capacity exhibits a slow fade from 117 down to $100 \mathrm{mAh} \mathrm{g}^{-1}$ over 400 cycles (open squares in Fig. 7). At the same rate, with a lithium intercalation limit of $0.25 \mathrm{Li}^{+}$, the anatase sample suffers drastic capacity fade over only a few hundred cycles (black circles, Fig. 7), thus confirming the superiority of $\mathrm{TiO}_{2}$ (B) structure to accommodate reversible lithium insertion due to larger channels.

After 400 cycles, the capacity for both $\mathrm{TiO}_{2}$ (B) electrode was limited at $0.25 \mathrm{Li}^{+}$per cycle, when the cycling rate was increased to $10 C$ or $12 C$. Both samples can sustain such high charge/discharge rate with only a small fade in capacity. When the rate is increased up to $24 C$ (one charge/discharge cycle in $5 \mathrm{~min}$ ), the electrode capacity still shows a steady capacity of about $56 \mathrm{mAh} \mathrm{g}^{-1}$. Long term cycling at $10 C$ rate (1360 cycles) leads to a regular fade in capacity which may originate from external parameters such as electrolyte evaporation inside the glove box or failure of the lithium counter electrode.

It must also be pointed out that when lithium intercalation in $\mathrm{TiO}_{2}(\mathrm{~B})$ is not limited, the capacity of the electrode drastically fades over a few cycles, especially at fast cycling rates.

At the light of the results of electrochemical tests, it is obvious that $\mathrm{TiO}_{2}(\mathrm{~B})$ can handle fast cycling rate with interesting specific capacity which makes it a promising negative electrode to be used in a hybrid cell associated to an activated carbon positive electrode.

The CV of PICACTIF activated carbon is depicted in Fig. 8. The shape is typical of a electrochemical double layer capacitance, and indeed, the galvanostatic plot (Fig. $)$ indicates a linear dependance of the voltage vs. time when the electrode is charged/discharged upon constant current. An highly reversible pseudoredox reaction can be seen at around $3.7 \mathrm{~V}$ versus $\mathrm{Li}^{+} / \mathrm{Li}$ (Fig. 8a) which does not interfer with the capacitance stability since the charge/discharge cycles efficiency (discharge time/charge time) is higher than 99\%. One can see that the CV of the 
activated carbon electrode is complementary from the one of $\mathrm{TiO}_{2}(\mathrm{~B})$, thus providing to the system a $3.7 \mathrm{~V}$ maximum cell voltage.

Fig. 8. (a) CV of the PICACTIF electrode at $1 \mathrm{mV} \mathrm{s}^{-1}$ and (b) galvanostatic charge/discharge of a PICACTIF electrode at $1 C$ rate (see Section $\underline{2}$ for preparation details).
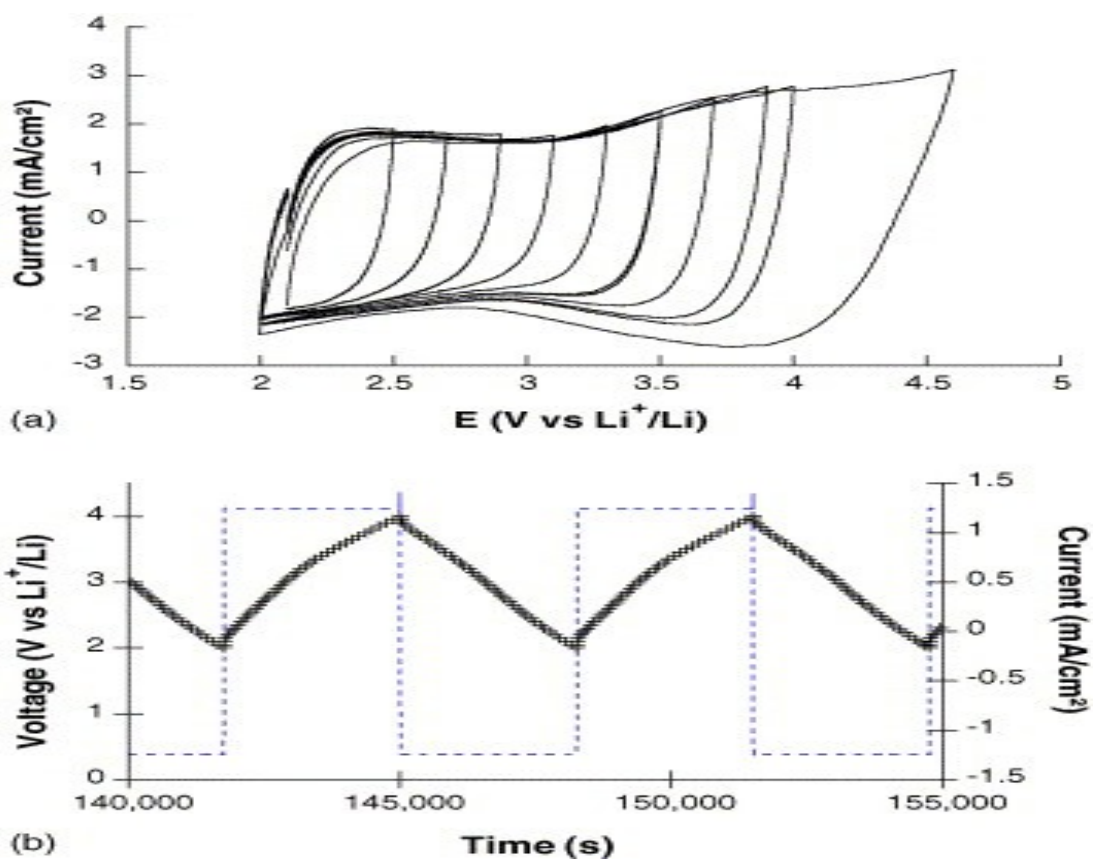

Fig. 9. Galvanostatic charge/discharge of a $\mathrm{TiO}_{2}$ (B)/PICACTIF hybrid cell at $9 C$ rate (see Section $\underline{2}$ for preparation details, $Q(+) / Q(-)=2.4 . V_{\max }$ cell $=3.2 \mathrm{~V}$.

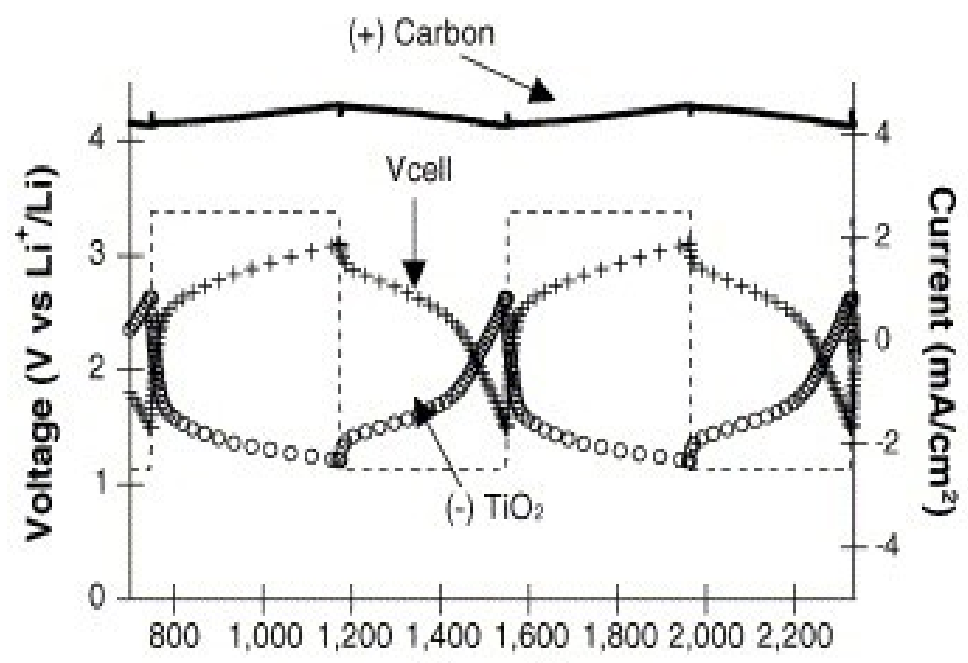

Time (s) 
The voltammetric charge calculated from the CV ( $\underline{\text { Fig. 8 }}$ a) gives a value of $46 \mathrm{mAh} \mathrm{g}^{-1}$ which is similar to that calculated from the galvanostatic tests $\left(47 \mathrm{mAh} \mathrm{g}^{-1}, \underline{\text { Fig. } 8}\right.$ b). This value is very close to that obtained from the activated carbon positive electrode in the study of Amatucci et al. [5]. The related capacitance of the PICACTIF carbon is $100 \mathrm{~F} \mathrm{~g}^{-1}$ which is a standard value exhibited by activated carbon in organic electrolytes [29].

Both electrodes, $\mathrm{TiO}_{2}(\mathrm{~B})$ as the negative and PICACTIF as the positive, were associated in an hybrid device together with a standard organic electrolyte, namely $1 \mathrm{M} \mathrm{LiPF}_{6}$ in ethylene carbonate: diethyl carbonate (Merck) 1:2. The separator was glass fiber paper. For the first experiments, an excess of activated carbon was used in order to obtain a charge ratio $Q(+) / Q(-)=2.4$. This excess in activated carbon was needed to limit the positive electrode potential drift to higher value during the first 10 cycles linked to the small irreversibility at the negative electrode (see discussion on Fig. 5). In such conditions, the hybrid device was cycled between $1.2 \mathrm{~V}$ and $3.2 \mathrm{~V}$. As depicted in Fig. 9, by constant galvanostatic cycling tests, $90 \%$ of the capacity is delivered by the hybrid device between $2.0 \mathrm{~V}$ and $3.2 \mathrm{~V}$.

From these first results, several hybrid cells were assembled, with equilibrated electrode weight, according to the voltammetric charge calculation of the positive and negative electrodes in their respective potential ranges. Subsequently, the mass ratio $\mathrm{m}\left(\mathrm{TiO}_{2}\right) / \mathrm{m}(\mathrm{PICACTIF})$ was 1.8 . The cell was cycled at different rates and with different maximum cell voltages. A galvanostatic plot $(2.5 C)$ of one of these cells is indicated in Fig. 10. In this case, the maximum cell voltage was set at $2.7 \mathrm{~V}$. As for the previous experiments (Fig. 9), the major part of the energy is delivered between $1.7 \mathrm{~V}$ and $2.7 \mathrm{~V}$.

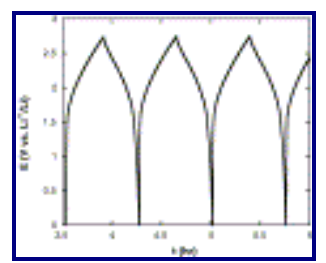

\section{Display Full Size version of this image (17K)}

Fig. 10. Galvanostatic charge/discharge of $\mathrm{TiO}_{2}$ (B)/PICACTIF hybrid cells at $2.5 \mathrm{C}$ rate between $0 \mathrm{~V}$ and $2.7 \mathrm{~V}$.

According to the total weight of active material, the different cells built as explained above exhibit energy densities between $45 \mathrm{Wh} \mathrm{kg}^{-1}$ and $80 \mathrm{Wh} \mathrm{kg}^{-1}$ with power densities in the range $240-420 \mathrm{~W} \mathrm{~kg}^{-1}$. These values are comparable to those reported by Amatucci et al. (58.5$85 \mathrm{Wh} \mathrm{kg}^{-1}$ ) [5] for their hybrid energy strorage device using $\mathrm{Li}_{4} \mathrm{Ti}_{5} \mathrm{O}_{12}$ instead of $\mathrm{TiO}_{2}(\mathrm{~B})$ as the negative electrode, and are well above those reported for other hybrid devices such as $\mathrm{Li}_{4} \mathrm{Ti}_{5} \mathrm{O}_{12} /$ poly(methyl)thiophene [8].

Long term stability of the hybrid device was achieved at different cell voltages as depicted in Fig. 11. As previously mentioned for the $\mathrm{TiO}_{2}$ (B) electrode, it takes a few cycles for the hybrid cell to reach its nominal energy density. This "activation" process is related to the faradic behavior of the $\mathrm{TiO}_{2}$ (B) electrode for which lithium intercalation is limited. This step seems of crucial importance for assuming high capacity and long term cycling behavior of the hybrid cell. When higher cell voltage $(3.5 \mathrm{~V})$ and higher cycling rate were used, lower specific energy were delivered by the system $\left(30 \mathrm{Wh} \mathrm{kg}^{-1}\right)$. After 600 cycles, the energy density has faded down to 
$20 \mathrm{Wh} \mathrm{kg}^{-1}$; however, this may be due to experimental details which will be avoided in packaged devices. Fig. 11 indicates that cell voltage, active material weight balance as well as cycling rates have to be further investigated to determine the optimum working conditions of the $\mathrm{TiO}_{2}$ (B)/activated carbon hybrid device.

Fig. 11. Long term stability of $\mathrm{TiO}_{2}$ (B)/PICACTIF hybrid cells at constant cycling powers, cell voltage limited at $2.75 \mathrm{~V}$ (black dots), and cell voltage limited at $3.5 \mathrm{~V}$ (open dots); energy and power densities are expressed per kilogram of total active materials $\left(\mathrm{TiO}_{2}(\mathrm{~B})+\right.$ activated carbon $)$.

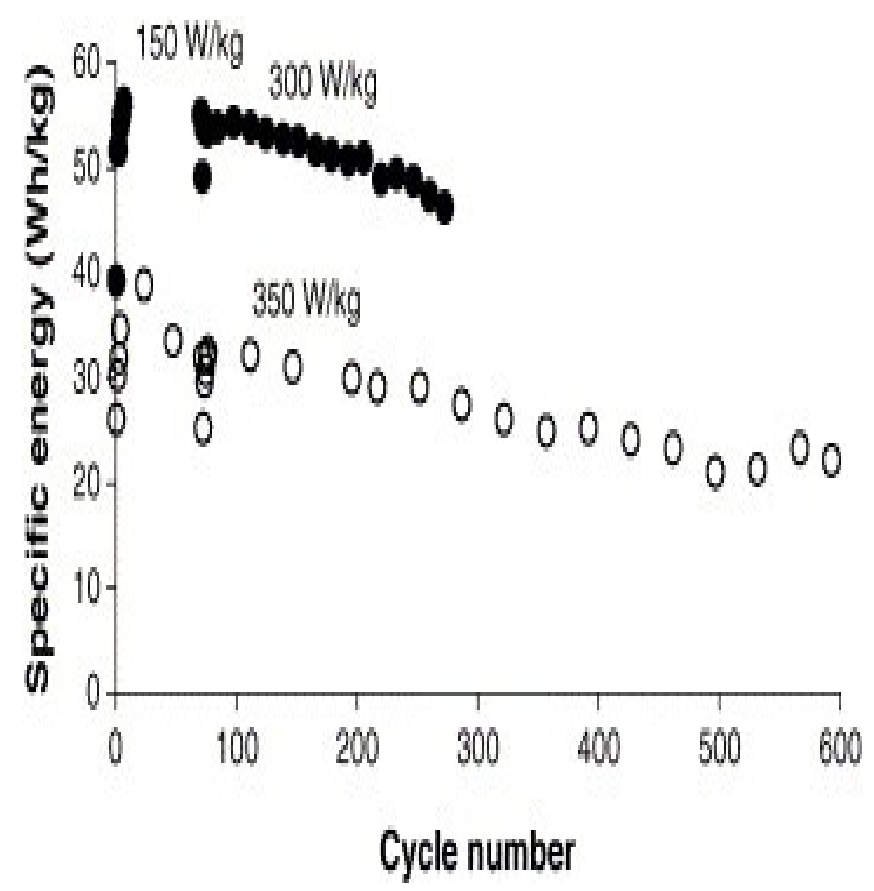

\section{Conclusion}

$\mathrm{TiO}_{2}(\mathrm{~B})$ has been investigated as a possible candidate to replace $\mathrm{Li}_{4} \mathrm{Ti}_{5} \mathrm{O}_{12}$ as a negative electrode for Li-ion battery. Long term stability of the $\mathrm{TiO}_{2}(\mathrm{~B})$ electrode can be obtained by limiting lithium intercalation to $0.35 \mathrm{Li}^{+}$per unit formula. Despite an unoptimized powder (particle size in the range of several micrometers) high cycling rate (up to 24C) can be used without noticeable degradation of the electrode. These performances allow us to assemble a nonaqueous hybrid energy storage device using $\mathrm{TiO}_{2}(\mathrm{~B})$ as the negative electrode and activated carbon as the positive, following previous studies of such high energy, high power storage device. The cells exhibit energy densities between $45 \mathrm{Wh} \mathrm{kg}^{-1}$ and $80 \mathrm{Wh} \mathrm{kg}^{-1}$ with power densities in the range $240-420 \mathrm{~W} \mathrm{~kg}^{-1}$ which are compatible with a fast charging/discharging device, intermediate between EDLC and Li-ion batteries. 
These performances allow to envision $\mathrm{TiO}_{2}(\mathrm{~B})$ as an interesting alternative to $\mathrm{Li}_{4} \mathrm{Ti}_{5} \mathrm{O}_{12}$ in a "powerful" charge storage device and future effort will be put on the synthesis of this material as a nanoscaled compound, as well as on the optimization of the hybrid cell working conditions.

\section{Acknowledgement}

The authors would like to thanks the PICA company for the activated carbon samples.

\section{$\underline{\text { References }}$}

M. Winter and R.J. Brodd, Chem. Rev. 104 (2004), pp. 4245-4269.

B.E. Conway, Electrochemical Supercapacitors, Scientific Fundamentals and Technological Applications, Kluwer Academic/Plenum Press, New York (1999).

D.A. Evans, Proceedings of the 5th International Seminar on Electrochemical Double Layer Capacitors and Similar Energy Storage Devices Florida Educational Seminars Inc. (1995).

T.Y. Chang, X. Wang, D.A. Evans, S.L. Robinson and J.P. Zheng, J. Power Sources 110 (2002), pp. 138-143.

G.G. Amatucci, F. Badway, A. Du Pasquier and T. Zheng, J. Electrochem. Soc. 148 (2001), pp. A930-A939.

A. Du Pasquier, I. Plitz, S. Menocal and G.G. Amatucci, J. Power Sources 115 (2003), pp. 171178.

A. Du Pasquier, I. Plitz, J. Gural, S. Menocal and G.G. Amatucci, J. Power Sources 113 (2003), pp. 62-71.

A. Du Pasquier, A. Laforgue, P. Simon, G.G. Amatucci and J.-F. Fauvarque, J. Electrochem. Soc. 149 (2002), pp. A302-A306.

C. Arbizzani, M. Mastragostino and M. Rossi, Electrochem. Commun. 4 (2002), pp. 545-549.

D.W. Murphy, R.J. Cava, S.M. Zahurak and A. Santoro, Solid State Ionics 9-10 (1983), pp. 413417.

K.M. Colbow, J.R. Dahn and R.R. Haering, J. Power Sources 26 (1989), pp. 397-402.

T. Brousse, P. Fragnaud, R. Marchand, D.M. Schleich, O. Bohnke and K. West, J. Power Sources 68 (1997), pp. 412-415.

D. Peramunage and K.M. Abraham, J. Electrochem. Soc. 145 (1998), pp. 2609-2614.

D. Peramunage and K.M. Abraham, J. Electrochem. Soc. 145 (1998), pp. 2615-2622.

A.N. Jansen, A.J. Kahaian, K.D. Kepler, P.A. Nelson, K. Amine, D.W. Dees, D.R. Vissers and M.M. Thackeray, J. Power Sources 81-82 (1999), pp. 902-905.

T. Ohzuku, A. Ueda and N. Yamamoto, J. Electrochem. Soc. 142 (1995), pp. 1431-1435.

J.P. Kartha, D.P. Tunstall and J.T.S. Irvine, J. Solid State Chem. 152 (2000), pp. 397-402.

R.K.B. Gover, J.R. Tolchard, H. Tukamoto, T. Murai and J.T.S. Irvine, J. Electrochem. Soc. 146 (1999), pp. 4348-4353.

R. Marchand, L. Brohan and M. Tournoux, Mater. Res. Bull. 15 (1980), pp. 1129-1133. 
L. Brohan and R. Marchand, Solid State Ionics 9-10 (1983), pp. 419-424.

M. Tournoux, R. Marchand and L. Brohan, Prog. Solid State Chem. 17 (1986), pp. 33-52.

B. Zachau-Christiansen, K. West, T. Jacobsen and S. Atlung, Solid State Ionics 28-30 (1988), pp. $1176-1182$.

G. Nuspl, K. Yoshizawa and T. Yamabe, J. Mater. Chem. 7 (1997), pp. 2529-2536.

H. Kawamura, Y. Muranishi, T. Miura and T. Kishi, Denki Kagaku 59 (1991), pp. 766-772.

B. Zachau-Christiansen, K. West, T. Jacobsen and S. Skaarup, Solid State Ionics 53-56 (1992), pp. 364-369.

A.R. Armstrong, G. Armstrong, J. Canales and P.G. Bruce, Angew. Chem. Int. Ed. 43 (2004), pp. 2286-2288.

M. Zukalovă, M. Kalbăč, L. Kavan, I. Exnar and M. Graetzel, Chem. Mater. 17 (2005), pp. 12481255.

J. Gamby, P.L. Taberna, P. Simon, J.F. Fauvarque and M. Chesneau, J. Power Sources 101 (2001), pp. 109-116.

P.L. Taberna, P. Simon and J.F. Fauvarque, J. Electrochem. Soc. 150 (2003), pp. A292-A300.

Corresponding author. Tel.: +332406831 73; fax: +33240683199.

\section{original text : Elsevier.com}

